\title{
Development and Validation of Information Technology Mentor Teacher Attitude Scale: A Pilot Study
}

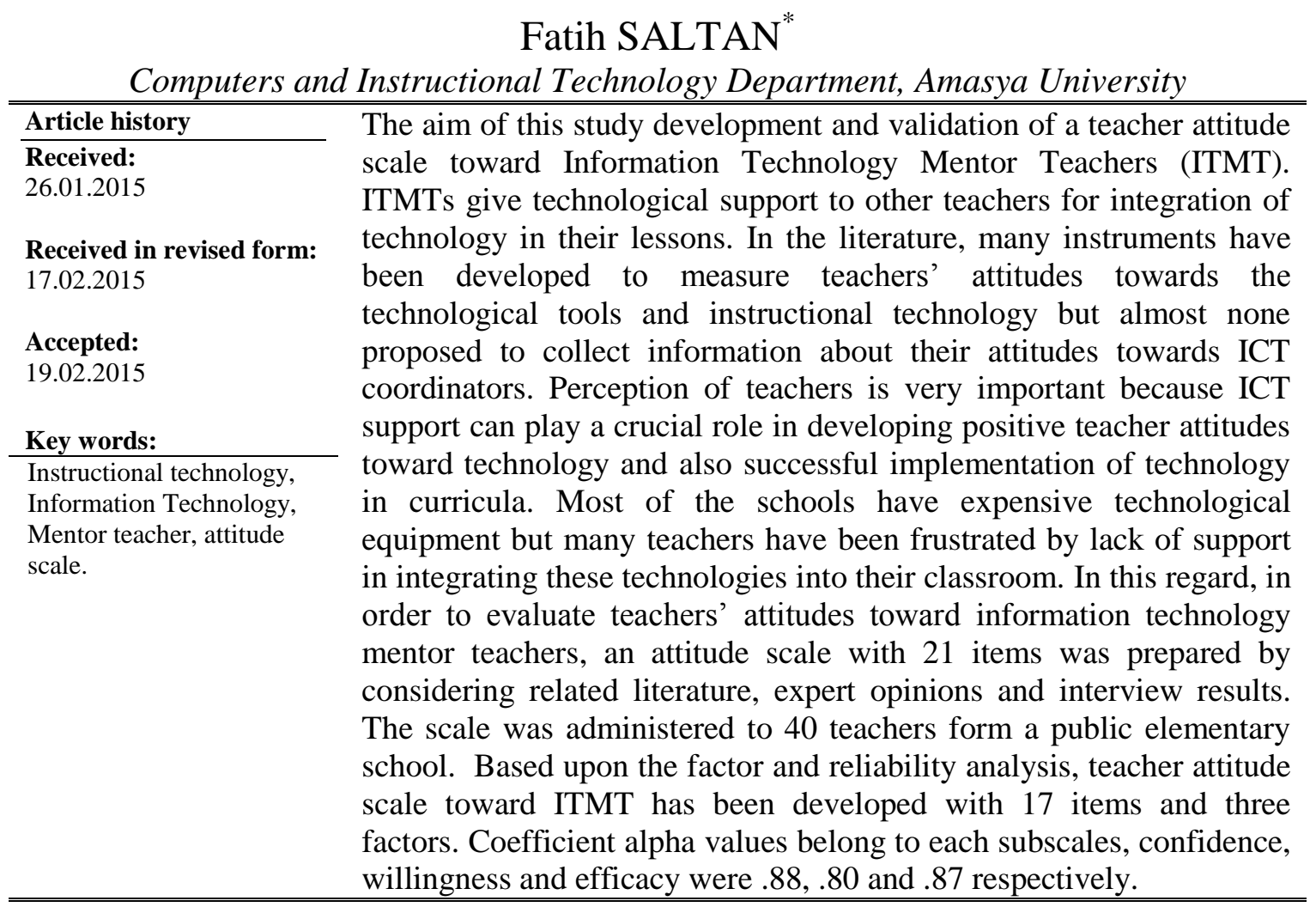

\section{Introduction}

Rapid development of technology made a considerable revision on instructional tools. Computer rooms, presentation rooms and intelligent white boards become very common in schools. It is expected teachers to integrate these technologies in their classroom. However, one of the most frequent issues raised by many studies is that teachers mostly used ICT in administrative tasks including preparation of unit plans, organizing scores and reporting (Usluel, Mumcu \& Demiraslan, 2007; Askar \& Usluel, 2003). Many scales have been developed to determine the teacher attitudes towards the technological tools that are used in education and over all instructional technology (Zhang, 2007; Christensen \& Knezek, 1998; Yavuz, 2005; Knezek \& Christensen, 1998; Tsai, Lin and Tsai, 2001). Many studies were conducted using such instruments. One of them is conducted by Pollard and Popiel (1994) in order to understand perception of preservice teachers toward technology and its use in the

\footnotetext{
*Correspondence:fsaltan@gmail.com
} 
classroom. 101 preservice teacher participated in this study and generally, respondents are positive toward their experiences with computer technology . They enjoy using computer and they want to learn more about it. Perception of preservice teachers is very important because preservice training can play a crucial role in developing positive teacher attitudes toward technology and also successful implementation of technology in education highly dependent upon the positive attitudes of teachers and administrators (Pina \& Harris, 1993; Woodrow, 1992). Unfortunately, faculty in teacher education programs often do not use technology themselves so the lack of effective technology training at the preservice level is considered a major impediment to the use of technology when new teachers enter the public school setting (Pollard \& Popiel, 1994). According to Hooker (2006), teachers are given expensive equipment, but they are often frustrated by lack of support in integrating it into their curriculum. Pina and Harris suggest that "the anxiety or confidence that teachers display towards computers and other new technologies is a subject which should be of prime importance to teacher educators and educational technologists" (1993). Another research on teachers' attitude towards computer was conducted by Cristenses (2002) with sixty teachers. Teachers were separated two groups and the treatment group takes computer instruction. After that data was gathered from both groups with the Teachers' Attitude toward Computers (TAC) questionnaire. The study showed that teachers in treatment groups changed to a great extent in direction of positive attitudes than other teachers. Besides, the study indicates that students' attitude are affected by teacher attitudes toward information technology. The recent study of the Albirini (2006) conducted with 326 Foreign Language teachers showed that the majority of teachers have the intention to learn about computers and to use them in the near future. As previous studies showed that, the result of the Albirini's study pointed to teachers' lack of computer competence as a main barrier to their acceptance and adoption of information and communication technology in developing countries (Albirini, 2006).

Since 1984 ICT was first introduced to schools, the Ministry of National Education (MONE) has allocated considerable funding for the use of instructional technologies in schools. The attempts have been made include in teacher training, courseware and educational material development and training of computer coordinators (Demiraslan\& Usluel, 2008). Especially after 2000, in order to effectively integration of instructional technology in education, MONE has started vocational programs to train ICT coordinator for schools. In these training programs, National Ministry of Education gives some teachers certification as an "Information Technology Resource Teacher" (ITRT). Now it is called "Information Technology Mentor Teacher" (ITMT). It was planned to provide ITMTs to use their time throughout the school year in order to give teachers technological support and change teachers' attitudes toward technology for integration of technology into the education.

Through the years, different roles have been assigned to the ICT coordinators. On the one hand, they defined as innovator or change agent who has an important role in educational policies of the countries ( Vanderlinde, van Braak, \& Hermans, 2009). On the other hand, the ICT coordinators defined as those who work and teach in schools based on the local needs and resources (Strudler \& Hearrington, 2008). Watson(2006) define ICT coordinator as "someone who can guide and support the school during the process of implementing ICT into education". Hancock (1990) looks from a different perspective and defines the ICT coordinator as a mentor for students who give support including hardware or software problems. British Educational Communications and Technology Agency (2002) emphasize that in recent practice the most common roles assumed by the ICT coordinator are technical support and supporting children during the learning process. The results of the one of the 
recent study which conduct quantitative and qualitative analysis showed that in practice the ICT coordinator functions dominantly in the role of technician (Devolder, Vanderlinde, van Braak, \& Tondeur, 2010).

In this regard, information technology resource teacher program is very recent in Turkey and there is not enough systematic research conducted to understand teachers' attitudes toward this innovative program. Moreover, many instruments have been developed to measure teachers' attitudes towards the technological tools and instructional technology but proposed to collect information about their attitudes towards ICT coordinators. Therefore, the study aims to develop a valid and reliable instrument to measure teachers' attitude towards ITMTs.

\section{State of the literature}

In the literature, many instruments have been developed to measure teachers' attitudes towards the technological tools and instructional technology but almost none proposed to collect information about their attitudes towards ICT coordinators.

Perception of teachers is very important because ICT support can play a crucial role in developing positive teacher attitudes toward technology and also successful implementation of technology in curricula.

Most of the schools have expensive technological equipment; similarly, many teachers are often frustrated by lack of support in integrating these technologies into their classroom.

\section{Contribution of this paper to the literature}

This study provides a literature review on instruments developed to measure teachers' attitudes towards the technological tools. The study also provides a valid instrument which was consisted of three subscales, confidence, willingness and efficacy. These are main subscales which affects teachers' attitudes towards ITMTs.

This certification program is very recent in Turkey and there is not enough systematic research to understand teachers' attitudes toward this innovation. This questionnaire may enable such researches.

\section{Method}

\subsection{Population and Sample}

Population of the pilot study is all primary school teachers which get support from Instructional technology resource teachers. The number of information technology resource teachers is very few in Turkey. All over the country about six hundred schools employed an instructional technology resource teacher. In this study convenient sampling method was utilized. The sample consisted of forty teachers from a primary school in Ankara. There were 27 female teachers and 13 male teachers. According to their branch, 2 Mathematic, 3 Turkish Language, 2 Science, 2 Social science, 4 English language, 3 Technology and design, 2 Religious and morality, 1 Computer, 1 Art, and 20 classroom teachers. 


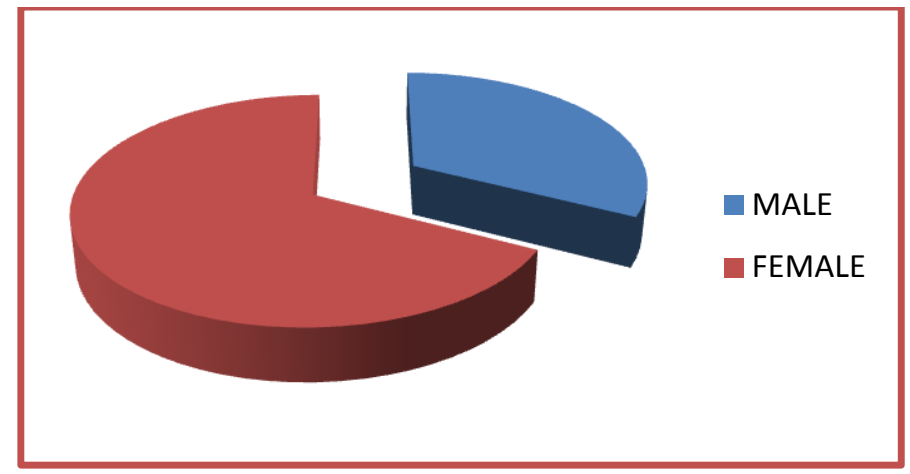

Figure1. Teachers' distribution according to gender

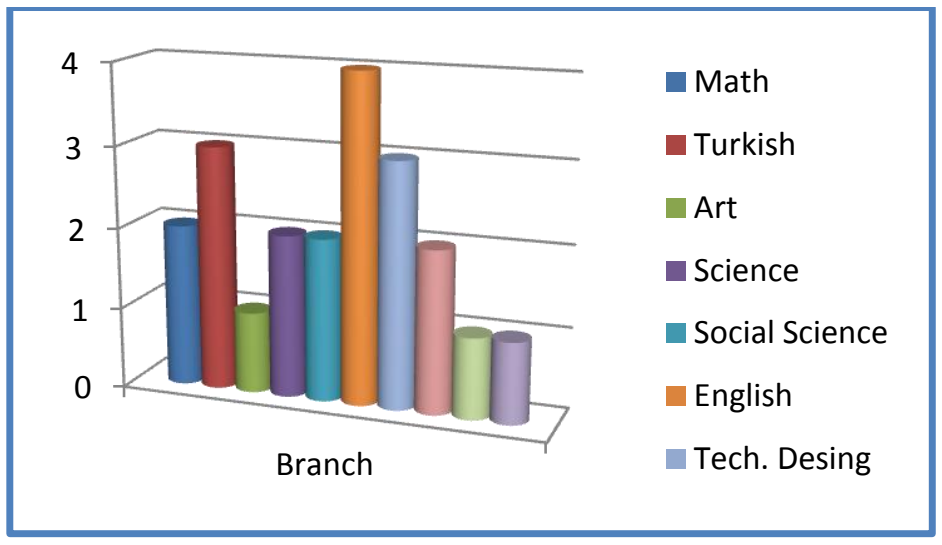

Figure2. Teachers' distribution according to branch

\subsection{Procedure}

During the study five main stages were followed. These steps are

(1) Developing conceptual framework for the instrument

a. Analysis of mission and function of the ITMTs

b. Analysis of the existing literature in the world

c. Interview with ITMT

(2) Developing item pool and constructing the instrument

(3) Taking expert opinion

(4) Cognitive interview

(5) Conducting survey

\subsubsection{Developing conceptual framework for the instrument}

In the first stage, firstly the mission and responsibilities of the information technology resource teachers in schools were examined. National Ministry of Education declares the terms of reference and job description of the ITRTs from its website (www.bitefo.meb.gov.tr). Four main dimensions were emerged from the analysis of this resource. The dimensions were entitled as integration of the technology into the lesson, technical support, material development and training. After that, in order to guide the development of the instrument, existing literature related to teachers' attitude toward instructional technology was examined. Under this frame, teachers' attitude toward computer, attitudes toward internet, attitudes toward instructional technology and attitudes toward 
information and communication technology were analyzed. Below, some basic questionnaires were summarized in terms of the items number and observed factors. In order to developed item pool in the next stage, the items which may be adapted for ICT coordinators were chosen here.

Teachers' attitude toward Instructional Technology (TAC)

Teachers' Attitudes toward Computers Questionnaire (TAC) is a 99-199 item Likert/Semantic Differential Instrument for measuring teachers' attitudes toward computers on 7-20 subscales (Christensen \& Knezek, 1998). It was seen in Table1.

Teachers' Attitudes toward Information Technology (TAT)

Teachers' Attitudes toward Information Technology (TAT) complements Teachers' Attitudes toward Computers Questionnaire to provide assessment in new information technologies. TAT also includes 2 subscales replicated from the Teachers' Attitudes toward Computers Questionnaire (Christensen \& Knezek, 1998). Table2 represented the subscales and alpha values.

Table 1 Internal Consistency Reliability for 7-Factor Structure of the TAC

\begin{tabular}{lll}
\hline Subscales & Alpha & No. of Variables \\
\hline F1 (Enthusiasm/Enjoyment) & .98 & 30 \\
F2 (Anxiety) & .98 & 30 \\
F3 (Avoidance/Acceptance) & .90 & 13 \\
F4 (E-mail for Classroom Learning) & .95 & 11 \\
F5 (Negative Impact on Society) & .85 & 11 \\
F6 (Productivity) & .96 & 30 \\
F7 (Kay's Semantic) & .94 & 10 \\
\hline
\end{tabular}

Table 2 TAT Internl Consistency Reliability

\begin{tabular}{lcc}
\hline Subscales & Alpha & No. of Variables \\
\hline Kay's Semantic (CAM) & .91 & 10 \\
Email (teacher) & .93 & 10 \\
Email (student) & .95 & 10 \\
WWW (teacher) & .95 & 10 \\
WWW (student) & .96 & 10 \\
Multimedia (teacher) & .96 & 10 \\
Multimedia (student) & .98 & 10 \\
Productivity (teacher) & .96 & 10 \\
Productivity (teacher) & .96 & 10 \\
D'Souza's Email & .95 & 11 \\
\hline
\end{tabular}

\section{Internet Attitude Scale (IAS)}

In the Zhang study (2007), the final instrument consisted of 40 items, with 10 items describing each of the four Internet attributes which are enjoyment, usefulness, anxiety, and self-efficacy.

Lastly an interview was made with an information technology resource teacher. Analysis of the interview showed similarity with literature and mission and faction definition of the Ministry of Education. Seven main dimensions were emerged from the analysis of the 
interview record. These were entitled as integration of the technology into the lesson, technical support, material development, training, maintaining computer rooms and keeping communication with technology department of the Ministry of Education.

In brief, result from all analysis and interview; four common teachers' attributes and four ITMT functions were observed. The teachers' attributes were Willingness/enjoyment, usefulness/efficacy, anxiety, and confidence. And ITMT factions were titled as integration of the technology into the lesson, technical support, material development and technical training.

\subsubsection{Developing item pool and constructing the instrument}

In the second stage, items pool was developed by considering the result of the first stage. The initial draft consisted of 56 items representing integration of the technology into the lesson, technical support, material development and technical training under the enjoyment, usefulness, anxiety, and confidence subscales.

\subsubsection{Taking expert opinion}

The draft was examined by 5 people, 3 of whom were working instructional technology area, one of whom was an expert on measurement and one of whom was a computer teacher. Some ambiguous or unclear items were reworded, and several items were removed according to the feedbacks. The final instrument consists of 21 items using 5-point Likert-type scale, where strongly disagree (1) to strongly agree (5). Among them, 6 items for willingness, 6 items for usefulness, 4 items for anxiety, and 5 items were constructed for confidence subscale.

\subsubsection{Cognitive interview}

In the fourth stage, a cognitive interview was made with a teacher which takes support from an ITMT. During this process think aloud protocol was followed. The think aloud method is a verbal protocol, which is accessible to anyone, as data thus creating an objective method (Someren, Barnard \& Sandberg, 1994). The final instrument was given the teacher and it was wanted him to think aloud while answering the items. Result of the cognitive interview showed that all items were clear and comprehensible.

\subsection{Data collection and analysis}

Data were collected from forty teachers from a public school in Ankara and analyzed in SPSS 11.5 statistical package program. Maximum likelihood with varimax rotation, a factor analysis, was utilized in order to explore the factor(s) structures. First of all, the basic assumptions that are examination of correlation matrix, Bartlett test of sphericity, and KMO value for factor analyses were tested. After that, a reliability analysis was conducted.

\section{Result}

In order to proceed with factor analysis, the value of Kaiser's Measure of Sampling Adequacy overall should be .60 or higher. In the study KMO's value indicated that there was a high correlation between all variables (.73). Also the assumption of sphericity was not violated $(\mathrm{p}<0.05)$. These results are summarized in Table 3. 
Table 3 Test of Kaiser

Kaiser-Meyer-Olkin Measure of Sampling Adequacy.

Bartlett's Test of Sphericity

$\begin{array}{lr}\text { Approx. Chi-Square } & 494.15 \\ \text { Df } & 210 \\ \text { Sig. } & .00\end{array}$

Before starting factor analysis, the correlation among 21 items was inspected to have a first look factorial structure. As seen in Appendix A high level of intercorrelation existed among half of the variables ( $p>.30)$. In order to decide factor number(s) eigenvalue and scree plot was used. Based on eigenvalue greater than 1 criteria, there were 6 factors. The eigenvalues and percentages of common variance explained by the factors were as follows: Factor 1, eigenvalue $=8.72$ (percentage variance $=41.50 \%$ ); Factor 2 , eigenvalue $=2.05$ (percentage variance $=9.74 \%) ;$ Factor 3, eigenvalue $=1.64($ percentage variance $=7.82 \%) ;$ Factor 4 , eigenvalue $=1.48$ percentage variance $=7.05 \%$ ) ; Factor 5 , eigenvalue $=1.16$ (percentage variance $=5.51 \%)$ and Factor 6, eigenvalue $=1.03$ (percentage variance $=4.89 \%)$. These finding are summarized in Table 4.

Table 4 The eigenvalues and percentages of common variance explained by the factors

\begin{tabular}{llll}
\hline & & & \\
Factor & Eigenvalue & \% of Variance & Cumulative \% \\
\hline 1 & 8,718 & 41,512 & 41,512 \\
2 & 2,046 & 9,741 & 51,254 \\
3 & 1,642 & 7,818 & 59,072 \\
4 & 1,481 & 7,052 & 66,124 \\
5 & 1,156 & 5,507 & 71,631 \\
6 & 1,027 & 4,892 & 76,523 \\
\hline
\end{tabular}

However, the range of the result of factor analysis indicated that items could not be distinctly loaded into six subscales. Also the literature indicated three to nine subscales. Therefore, the factor analysis again ran restricting the number of factor to three. According to the result; $15^{\text {th }}, 16^{\text {th }}, 17^{\text {th }}, 18^{\text {th }}$, and $8^{\text {th }}$ items were found to be in the first; $1^{\text {st }}, 2^{\text {st }}, 3^{\text {rd }}, 7^{\text {th }}$, and $13^{\text {th }}$ in the second; $5^{\text {th }}, 10^{\text {th }}, 11^{\text {th }}, 12^{\text {th }}, 19^{\text {th }}, 20^{\text {th }}$ and $21^{\text {th }}$ in the third factor. $4^{\text {th }}, 6^{\text {th }}, 9^{\text {th }}$ and $14^{\text {th }}$ items were loaded any of the three factors. Table 5 shows the factor loading values in detail. Factors were named according to contend of the items and the literature. The items in the first factor were called "Confidence", the ones in the second factor were called "Willingness"; the ones in the third factor were called "Usefulness".

After factor analysis, reliability was checked. The widely-accepted social science cut-off is that Coefficient alpha should be .70 or higher for a set of items to be considered a scale. In the study Coefficient alpha values belong to each subscale, Confidence, Willingness and Usefulness were $.88, .80$ and .87 respectively. Also when we examine the Deleted-item Cronbach's alpha values it was seen to drop any items from any of factors did not increase Cronbach's alpha value. 
Table 5 Factor Loading

\begin{tabular}{|c|c|}
\hline Item & $\begin{array}{l}\text { Factor } \\
\text { Loadings }\end{array}$ \\
\hline \multicolumn{2}{|l|}{ Factor1: Confidence $(\alpha=.88)$} \\
\hline 15. I can use learning materials in my class successfully with the help of ITMT. & .63 \\
\hline 16. I can improve my computer abilities getting support from ITMT. & .52 \\
\hline $\begin{array}{l}\text { 17. I can use new instructional technologies in my class successfully with the help of } \\
\text { ITMT. }\end{array}$ & .54 \\
\hline 18. I can prepare the lessons on my own previously taking the help of ITMT. & .96 \\
\hline 8. I want to get support from ITMT about technical issues. & .85 \\
\hline \multicolumn{2}{|l|}{ Factor2: Willingness $(\alpha=.80)$} \\
\hline 1. I want to get support from ITMT to use technologies more effectively in my classes. & .39 \\
\hline 2.Getting support from ITMT make my work easir. & 1.00 \\
\hline 3. I feel disturbed getting support from ITMT while preparing my class. & .75 \\
\hline 7. I feel disturbed getting support from ITMT while developing learning materials. & .65 \\
\hline 13. I don’t want to get support from ITMT while preparing my class. & .39 \\
\hline \multicolumn{2}{|l|}{ Factor2: Usefulness/Efficacy $(\alpha=.87)$} \\
\hline 5. I want to improve my materials by getting support from ITMT. & .58 \\
\hline 10. I want to improve my computer abilities getting support from ITMT. & .48 \\
\hline $\begin{array}{l}\text { 11- The materials prepared by getting support from ITMT are more effective for learning } \\
\text { of students. }\end{array}$ & .56 \\
\hline 12- ITMT encouraging teachers to develop their own skills. & .41 \\
\hline 19. Taking support from ITMT useful in the development of my computer skills. & .33 \\
\hline $\begin{array}{l}\text { 20. Developing learning materials by taking support from ITMT improve the effectiveness } \\
\text { of my classes. }\end{array}$ & 1.06 \\
\hline 21. Preparing classes by taking support from ITMT improve efficiency. & .59 \\
\hline
\end{tabular}

\section{Discussion and Conclusions}

Results of the literature review and interview analysis four common teachers' attributes were indicated which are willingness/enjoyment, usefulness/ efficacy, anxiety, and confidence, and four main missions of ITMTs which were integration of the technology into the lesson, technical support, material development and technical training. Regarding these, an item pool was generated with 51 items. After taking experts' opinions, item number was decreased up to 21; six for enjoyment, four for anxiety, five for confidence and six for usefulness / efficacy. In order to support content validity, beside the review of relevant literature and taking expert opinion the instrument was checked by an ICT teacher, graduated from an educational technology program, in terms of the content relevance and wording. The instrument was applied to 40 teachers in a public school. Maximum likelihood with varimax rotation, a factor analysis, was utilized in order to explore the factor(s) and check the reliability of the instrument. Instead of four, six factors were observed. However, items could not be distinctly loaded into six subscales. On the other hand the literature indicated three to nine subscales. Restricting the number of factor to three, the factor analysis ran one more times and the result showed that three-factor construct was more meaningful for this study. The items in the first factor were called confidence, the ones in the second were called usefulness and the ones in the third were called willingness. Two anxiety items were gathered in the third factor. It can be reason that anxiety items could not be clearly understood or the number of anxiety items could not sufficient. In further studies, the number of anxiety items should be revised and increased. On the other hand, $4^{\text {th }}, 6^{\text {th }}, 9^{\text {th }}$ and $14^{\text {th }}$ items did not load any 
of the three factors. Therefore it was decided to omit these items from the scale. The Coefficient alpha values belong to each subscale, confidence, willingness and efficacy were $.88, .80$ and .87 respectively. These values supported reliability of the scale. This scale can be very helpful because ITMT certification is a hot topic in agenda of the National Ministry of Education. In the near future, there would be an ITMT in every school but there were not sufficient studies about teachers' perception toward ITMTs. Current study provided a reliable scale to collect data in this regard. As Strudler, Falba and Hearrington (2001) highlighted that educational change regarding ICT is a continuous progress and demands ongoing coordination and support. Educational technologist need to gather reliable information in all stages of technology integration. Surely, this survey could be helpful to understand what teachers think about ITMT. On the other hand, because the sample size was limited in this study a further study should be conducted before the instrument was applied extensively. In light of this pilot study, ITMT attitude scale might be revised and a new study should be conducted with larger sample. It may be needed to validate such a instrument in various schools which have different ICT facilities including interactive white boards, tablets and computer labs. 


\section{Appendix A -Correlation Matrix}

\begin{tabular}{|c|c|c|c|c|c|c|c|c|c|c|c|c|c|c|c|c|c|c|c|c|c|}
\hline $\mathrm{s}$ & S1 & S2 & S3 & S4 & S5 & S6 & S7 & S8 & S9 & S10 & S11 & $\mathrm{S} 12$ & $\mathrm{~S} 13$ & S14 & S15 & S16 & S17 & S18 & S19 & S20 & S21 \\
\hline S1 & $\begin{array}{r}1, \\
00 \\
0\end{array}$ & , 429 & 592, & ,515 & 255 & 158 & ,527, & 485, & ,341 & 496, & 463, & 409, & 173, & 344, & ,527 & 455, & ,580 & ,537, & ,442 & ,411 & 432 \\
\hline S2 & $\begin{array}{r}, 4 \\
29\end{array}$ & $\begin{array}{r}1,00 \\
0\end{array}$ & ,758 & ,307 & ,367 & ,256 & , 325 & 267, & ,365 & ,398 & 265 & 236 & 455, & ,331 & ,308 & 263 & ,512 & ,235 & ,380 & ,282 & 624 \\
\hline S3 & $\begin{array}{r}, 5 \\
92\end{array}$ & ,758 & $\begin{array}{r}1,00 \\
0\end{array}$ & , 195 & ,175 & ,154 & 675, & ,242 & 403, & ,379 & 407, & 196, & ,338 & 268, & , 350 & ,350, & 607, & 278, & ,356 & ,191 & ,566, \\
\hline S4 & $\begin{array}{r}, 5 \\
15\end{array}$ & 307, & 195 & $\begin{array}{r}1,00 \\
0\end{array}$ &, 520 & ,330 & ,214 & ,403 & 096 & ,337, & ,371 & ,381 & ,063 & 230, & 291 & 249, & 457, & 437, & ,371 & ,709 & 335, \\
\hline S5 & $\begin{array}{r}, 2 \\
55\end{array}$ & ,367 & ,175, &, 520 & $\begin{array}{r}1,00 \\
0\end{array}$ & ,245 & 008 & 209, & 066 & ,345 & ,360 &, 541 & ,112 & ,218 & ,124 & ,223 & ,303 & ,259 & ,184 &, 549 & 415, \\
\hline S6 & $\begin{array}{l}, 1 \\
58\end{array}$ & ,256 & 154 & ,330 & 245 & $\begin{array}{r}1,00 \\
0\end{array}$ & 096 & 091 & 200 & 152 & 070, & ,276 & 279, & ,031 & 277, & ,341 & , 190 & ,112 & ,101 & ,244 & ,073 \\
\hline S7 & $\begin{array}{r}, 5 \\
27\end{array}$ & ,325 & 675, & ,214 & ,008 & 096, & $\begin{array}{r}1,00 \\
0\end{array}$ & 212 & ,460 & ,354 & 462 & 179 & ,238 & 256 & 297 & 303, & 495 & 287 & 4411 & ,130 & 288 \\
\hline S8 & $\begin{array}{r}, 4 \\
85\end{array}$ & 267, & 242 & 403 & 209 & ,091 & 212 & $\begin{array}{r}1,00 \\
0\end{array}$ & ,175 & ,504 & ,311, & 271 & 140, & 490, & 587, & 370, & ,589 & 752, & ,561 & ,335 & ,351 \\
\hline S9 & $\begin{array}{r}3 \\
41\end{array}$ & ,365 & 403, & 096 & ,066 & 200 & ,460 & 175 & $\begin{array}{r}1,00 \\
0\end{array}$ & 640, & ,519 & ,143 & 243, & ,393 & ,565, & 276, & ,388 & ,316 & ,519, & ,319 & ,539 \\
\hline S10 & $\begin{array}{c}, 4 \\
96\end{array}$ & ,398 & ,379 & ,337 & ,345 & ,152 & ,354 & ,504 & 640, & $\begin{array}{r}1,00 \\
0\end{array}$ & ,727 & ,396 & 181, & 464, & 537, & ,350 & 483 & ,538 & 647, & ,634 & 695, \\
\hline S11 & $\begin{array}{l}, 4 \\
63\end{array}$ & 265 & 407, & ,371 & ,360 & ,070 & ,462 & ,311 & ,519 & ,727, & $\begin{array}{r}1,00 \\
0\end{array}$ & ,582 & 079, & 433, &, 372 & 267, & ,589 & ,422 & ,512 & ,642 & ,705 \\
\hline S12 & $\begin{array}{c}, 4 \\
09\end{array}$ & ,236 & 196, & ,381 &, 541 & 276 & 179, & ,271 & 143 & ,396, & ,582 & $\begin{array}{r}1,00 \\
0\end{array}$ & ,013 & ,234 & 297 & ,329 & ,396 & 335, & ,225 & ,481 & ,452 \\
\hline $\mathrm{S} 13$ & $\begin{array}{l}, 1 \\
73\end{array}$ & 455, & ,338 & ,063 & ,112 & ,279 & ,238 & 140 & 243, & ,181 & 079, & 013, & $\begin{array}{r}1,00 \\
0\end{array}$ & ,191 & 144 & 171 & 181 & , 149 & ,243 & - 063 & 202 \\
\hline S14 & $\begin{array}{r}, 3 \\
44\end{array}$ & ,331 & 268 & ,230 & 218, & ,031 & ,256 & 490, & ,393 & ,464 & 433, & ,234 & 191, & $\begin{array}{r}1,00 \\
0\end{array}$ & ,504 & 238, & ,341 & 232 & ,539 & ,349 & 377, \\
\hline S15 & $\begin{array}{r}, 5 \\
27\end{array}$ & ,308 & ,350 & 291 & ,124 & 277 & 297 & 587, & ,565 & 537, & ,372 & 297, & 144, &, 504 & $\begin{array}{r}1,00 \\
0\end{array}$ & 677, & 674 & ,612 & ,627 & ,480 & ,530 \\
\hline S16 & $\begin{array}{r}, 4 \\
55\end{array}$ & ,263 & ,350 & ,249 & ,223 &, 341 & ,303 & ,370 & ,276 & ,350 & 267, & ,329 & ,171 & ,238 & 677, & $\begin{array}{r}1,00 \\
0\end{array}$ & ,541 & ,541 & ,383 & ,297 &, 322 \\
\hline S17 & $\begin{array}{r}5 \\
80\end{array}$ &, 512 & 607, & 457, & ,303 & 190 & 495, & ,589 & ,388 & 483 & ,589, & ,396 & 181 & ,341 & 674 &, 541 & $\begin{array}{r}1,00 \\
0\end{array}$ & ,711 & 647, & ,473 & 695, \\
\hline S18 & $\begin{array}{r}, 5 \\
37\end{array}$ & ,235 & ,278 & 437, & 259 & ,112 & ,287 & ,752 & ,316 & ,538 & ,422 & ,335 & 149, & ,232 & ,612 & ,541 & ,711 & $\begin{array}{r}1,00 \\
0\end{array}$ & ,605 &, 352 & ,443 \\
\hline S19 & $\begin{array}{r}, 4 \\
42\end{array}$ & 380 & ,356 & ,371 & ,184 & ,101 & ,411 & ,561 &, 519 & 647, &, 512 & ,225 & ,243 & ,539 & 627, & ,383 & ,647 & 605, & $\begin{array}{r}1,00 \\
0\end{array}$ & ,561 & 607, \\
\hline S20 & $\begin{array}{l}, 4 \\
11\end{array}$ & ,282 & ,191 & 709, & ,549, & ,244 & ,130 & 335, & ,319 & 634, & 642 & 481, & , 063 & ,349 & 480, & 297, & ,473 & ,352 &, 561 & $\begin{array}{r}1,00 \\
0\end{array}$ & 678 \\
\hline S21 & $\begin{array}{r}, 4 \\
32\end{array}$ & ,624 & ,566 & ,335 & ,415 & ,073 & ,288 & ,351 & ,539 & 695, & ,705 & ,452 & 202 & ,377 & ,530 & ,322 & 695, & ,443 & 607, & 678 & $\begin{array}{r}1,00 \\
0\end{array}$ \\
\hline
\end{tabular}




\section{References}

Albirini, A. (2006). Teachers' attitudes toward information and communication technologies: The case of Syrian EFL teachers. Computers \& Education, 47(4), 373-398.

Askar, P. \& Usluel, Y. K. (2003). A longitudinal study related to the rate of adoption of computers: Comparison of three schools. Hacettepe University Journal of Education, 24, 15-25.

British Educational Communications and Technology Agency. (2002). Final report on the roll out of the NGfL programme in ten pathfinder LEAs. Retrieved from 27-08-2008.

Christensen, R. (2002). Effects of technology integration education on the attitudes of teachers and students. Journal of Research on technology in Education, 34(4), 411433.

Christensen, R. and Knezek, G. (1998). Parallel Forms for Measuring Teacher's Attitudes Toward Computers. Proceedings of SITE 98. Association for the Advancement of Computing in Education: Charlotteville, VA, p 831-832.

Demiraslan, Y., \& Usluel, Y. K. (2008). ICT integration processes in Turkish schools: Using activity theory to study issues and contradictions. Australasian Journal of Educational Technology, 24(4), 458-474.

Devolder, A., Vanderlinde, R., van Braak, J., \& Tondeur, J. (2010). Identifying multiple roles of ICT coordinators. Computers \& Education, 55(4), 1651-1655.

Hancock, V.E. (1990). Promoting secondary school computer use? A coordinator is the key. Paper presented at the meeting of the International Conference on Technology and Education, Brussels, Belgium.

Knezek, G. \& Christensen, R. (1998). Internal Consistency Reliability for the Teachers Attitudes toward Information Technology (TAT) Questionnaire. Proceedings of the Society for Information Technology \& Teacher Education, 2, 832-833

Maarten W. ,Yvonne F. Barnard \& Jacobijn A.C. Sandberg (1994), A practical guide to modelling cognitive processes, Published by Academic Press, London, 1994 ISBN 012-714270-3

Strudler, N. B., \& Hearrington, D. (2008). Quality support for ICT in schools. In J. Voogt, \& G. Knezek (Eds.), International handbook of information technology in primary and secondary education (pp. 579-596). New York: Springer.

Pollard and Popiel (1994), An analysis of the perceptions of preservice teachers toward technology and its use in the classroom, Journal of Instructional Psychology; Jun94, Vol. 21 Issue 2, p131, 8p, 1 chart

Pina A. \& Harris B.R. (1993), Increasing Teachers' Confidence Computer for Education, Paper presented at the annual conference of the Arizona Educational Research Organization.

Tsai, C.-C., Lin, S. S. J. and Tsai, M.-J., (2001). Developing an Internet Attitude Scale for high School Students, Computers and Education, vol. 37, no.1, p41-51.

Usluel, Y., Mumcu, F. \& Demiraslan, Y. (2007). ICT in teaching-learning process: Teachers' views on the integration of ICT and on the perceived obstacles to this integration. Hacettepe University Journal of Education, 32, 164-179.

Vanderlinde, R., van Braak, J., \& Hermans, R. (2009). Educational technology on a turning point; curriculum implementation in Flanders and challenges for schools. Educational Technology Research and Development, 57, 573-584.

Yavuz S. (2005), Developing a Technology Attitude Scale for Pre-Service Chemistry teachers, TOJET January 2005 ISSN: 1303-6521 Volume 4, Issue 1, Article 2 
Zhang, Y. (2007). Development and validation of an internet use attitude scale. Computers \& Education 49 (2007) 243-253.

Watson, D. (2006). Understanding the relationship between ICT and education means exploring innovation and change. Education and Information Technologies, 11, 199216. 